\title{
WITH ELEPHANTS AND PANNIKANS IN CEYLON
}

\author{
By Major A. N. WienaraN \\ Director, Zoological Gardens of Ceylon
}

When I first visited Ruaneliya Estate in the Bingiriya area, 75 miles from the heart of the city of Colombo, 200 of its 1,200 acres were under coconuts, the rest was jungle. In spite of occasional raids by elephants, the coconuts did well; but as surrounding areas were opened up, the elephants became isolated in Ruaneliya and the surrounding jungles and their visits to the coconut plantation became more and more frequent.

Many ingenious attempts were made to keep the elephants away. Electrified fencing, electric trip-wires connected to klaxons, rope fire crackers, ignited motor tyres and even a protective ditch, were all tried in their turn, but the elephants could not be stopped. The electrified fences were shortcircuited, by a branch being pulled on to the wire; the klaxons blared forth when the trip-wire was touched, and the elephants raced away madly, but only to return as soon as the current was switched off. The noise of the fire crackers scared them away, but as soon as it ccased they were back again; likewise the ignited motor tyres kept them away for some time, but they soon learnt to avoid them and even began contemptuously to kick them out of the way. The ditch worried them for a little longer but they began to slide down on their bottoms into the moat, grasp a tree on the opposite bank with their trunks and haul themselves out on the other side.

At this stage the estate was bought by Mr. Aloy Jayakody. He found that a 40-acre field, fully planted with coconuts, had become the elephants' stamping ground. Four trees remained, and these stood only because they happened to be firmly implanted on termite hills. Their trunks were smooth and polished by the frequent rubbing and pushing of elephants.

Soon the elephant menace reached its peak and Mr. Jayakody was faced with the grim, stark reality of his property being steadily devastated. He applied for permission to capture a few elephants, in the hope that the remainder would withdraw to a respectful distance. Permission to capture was refused, but Mr. Jayakody was informed that the law permitted shooting in defence of crops. There being no alternative Mr. Jayakody ordered that trespassing elephants were to be shot. 
Within a year some twenty-two elephants were killed, many of them having to be cremated because they fell close to human habitations. When the twenty-third animal was burned, it burst open and a fully formed baby elephant was exposed. Mr. Jayakody was shattered by this tragedy and made up his mind that there would be no further shooting without another strenuous effort to obtain a permit to capture. Eventually, with the help of the late Mr. A. C. Tutein-Nolthenius, Sir John Kotelawala, then prime minister, and Mr. Eric Wickremanayake, president of the Ceylon Wild Life Protection Society, it was decided to issue permits to the director of the Colombo Zoo to capture elephants until the pocketed Ruaneliya herd, estimated at sixty-five animals, was extinguished.

So far we have taken fifteen animals. The largest was a $7 \mathrm{ft} .6$ in. female, blind in one eye, the smallest a little male of 5 feet. Every animal without a single exception has carried gunshot wounds, some completely healed.

Capture is organized by me and the entire operation planned and carried out under my close supervision. The actual trapping is done by Pannikans, under the personal direction of Mr. Jayakody or myself. The utmost vigilance is necessary to cnsure that the Pannikans are not cruel and only shoot elephants if human life is seriously threatened. Up to now not a single animal has been shot, but this does not mean that truculent beasts have not been encountered and driven away by ingenious, humane methods.

The Pannikans come from Moorish villages in the north and north-east of the island, and belong to families who have for generations been engaged in the art of noosing elephants. In olden times the elephants were disposed of to Arabs who undoubtedly sold them to princes and rajahs in India with whom elephants were in great demand. Right down to the present day the Ceylon elephant's reputation for intelligence, docility and faithfulness is very high. These Pannikans are able to track elephants through the jungle almost instinctively and display the greatest courage and resource when doing so. They are so daring and confident that they go into the jungles unarmed, and put to shame the modern sportsman with his high-powered magazine rifle.

About ten or fifteen of these intrepid hunters go into the jungle, carrying nothing with them, apart from the inevitable chew of betel and a few fire crackers, except a flexible rope made of sambar hide which they endeavour to secure to the hind legs of an elephant. 'These ropes are made of no less than seventy- 
five slender thongs twisted together and are very strong. In fairly open jungle the Pannikans steal up to a selected animal and slip a noose over its hind leg, almost simultaneously fastening the other end to a tree. The rest of the herd are scared away by fire crackers and shouts. Meanwhile the captured elephant is straining at the rope which holds him and the Pannikans striving to fasten ropes to his other legs and neck. Eventually they tie him fast.

In thick forests the Pannikans adopt a different method. First they choose a suitable place on the elephants' way to water. Here they dig a hole 18 inches deep, with a circumference twice that of the forefoot of the elephant they intend to capture - the circumference of an elephant's forefoot is half its height. In this hole, a few inches below ground, they put a slip noose, taking the other end of the rope, under the ground and over the branch of a tree, to a heavy boulder or bag of earth. This weight is held up by a rough wooden spring trap. The ground all around is camouflaged and a dry branch is put just in front of the hole containing the noose. In trying to avoid the branch, the elephant puts his foot in the hole, springs the trap and the weight at the end of the rope tightens the noose round his leg. He is now caught and unless he can break the rope before the Pannikans have time to secure him further, has no chance of escape.

Shortly after capture the animal is conducted to a camp which is usually close by, and securely tethered there. Fires are lighted round the camp to prevent his companions attempting a rescue, and he is not allowed to sleep. The technique is to allow him to get fairly exhausted, and as soon as he becomes subdued and quiet he is supplied with bananas, sugar cane and other delicacies and also given water to drink, which by that time he is craving for. Within a few days he is sufficiently reconciled to his fate to permit removal to the place where his real education is to be carried out.

If the elephants I capture are under $6 \frac{1}{2}$ feet, I load them into my lorry with the help of the Pannikans and bring them down to Colombo within 24 hours of their capture. They are then taken over by a big monitor elephant I have named Letchmi. She is $8 \frac{1}{2}$ feet high and quite accustomed to dealing with wild elephants. Within three months the new arrivals are usually tame and ready for training.

One day when I was out with the Pannikans, we drove in a jeep along the barbed wire fence surrounding the Ambakelle Coconut Seed Station at Ruaneliya. The wire had been pushed 
down in half a dozen places and as the elephant spoor was quite fresh, it was evident that they could not be far away. The Pannikans produced toy balloons which they blew up and ticd to the ends of short sticks. Holding these before them in order to be able to keep to the leeward side of the herd whose presence was becoming more and more apparent, we advanced slowly and as noiselessly as we could, till we got a glimpse of a marsh where a number of elephants of various sizes were resting.

The elephants were in low grass; so manœuvring myself into a point of vantage $I$ tried to count them. It was not easy because they kept on moving about and changing places, but as near as I could make out there must have been at least thirty. There were several very large ones, many in the range of 5 to 6 feet and a few babies. It was a lovely sight watching the babies who seemed to be playing hide and seek, dodging between the legs of the bigger animals. After watching them for ten minutes we slowly retired to the jeep. We had to be very cautious as we did not want to excite the elephants, because it was a suitable place in which to lay traps, and it would have been tragic if we disturbed them and they got on the move again. We decided, after taking stock of the situation, that the clephants should be allowed to settle down as they appeared a little restless.

I ordered the head Pannikan to keep on the heels of the herd and to summon more Pannikans and get more ropes, for there were signs that the drought was going to continue and, with the drying up of water holes, it would be easier to make captures.

Just a week later a 7-ft. female was trapped and well secured. At noon the operation of leading her into the estate started, with the assistance of a couple of tame elephants between whom she was securely tied. She strained and tugged and very nearly escaped into the jungle with the two tame elephants, but fortunately one fell and her progress was arrested. Ropes had to be used to get the tame elephant on its feet again, and it was not until 3 a.m. the following day that the captured female was finally tied to two stout coconut trees near Aloy's bungalow at Ruaneliya.

The captured elephant is quite a nice animal, about 14 years old, and as she is very strong the problem of moving her to the Zoo is not an easy one. She will have to be marched down between two strong tame elephants, walking 15 miles a day from midnight till dawn. The rest of the time she will have to be tied up in a quiet spot and food and water carried to her by the tame elephants. At the time of writing I have 
not been able to arrange for her removal to Colombo as four more elephants were trapped within the next 48 hours. These were small ones about $5 \frac{1}{2}$ feet in height and have been brought down to the Zoo by lorry.

The trappers are still out and I hope to take a few more elephants provided the rains keep off. Every elephant captured is an elephant saved, as these poor creatures are being mercilessly shot when they stray into cultivated areas.

This is not the only "pocketed" herd in Ceylon, for the indiscriminate felling of forests, without providing corridors for the elephants to roam from one jungle into the other in search of food and water, has resulted in their being imprisoned in restricted areas. There is no hope for them unless they are trapped and brought into captivity. They are being shot at every day, and one seldom opens a paper without reading a harrowing story of another elephant being shot. The whole elephant situation in Ceylon is most unsatisfactory. The human population has increased to such an extent that all available land has to be opened up in an endeavour to increase food production. Elephants are becoming more and more confined, and unless measures are taken to protect a limited number and not allow them to fall below the biological minimum, the time is not far off when the Ceylon elephant will be as dead as the Dodo.

There is no policy at present other than rapidly cutting down forests and at the same time hoping that all the elephants will survive! It is not too late but soon will be, unless we get an expert from outside, who is unprejudiced and commands the confidence not only of wild life preservation organizations, but also of those concerned with world food, to come to Ceylon, plan an elephant census and recommend conservation methods. It is now a matter of international importance. Perhaps it will be possible to obtain international help, financial and otherwise, to mect an appeal of such grave national importance as "Save the Crops, Save the Cultivators and Save the Elephants". 